\title{
Quantitative Response of Maize Vcmax25 to Persistent Drought Stress at Different Growth Stages
}

\author{
Xingyang Song ${ }^{1,2}$, Guangsheng Zhou ${ }^{2,3,4, *(\mathbb{D},}, \mathrm{Qijin}^{\mathrm{He}}{ }^{5}$ and Huailin Zhou ${ }^{2} \mathbb{C}$ \\ 1 College of Applied Meteorology, Nanjing University of Information Science \& Technology, \\ Nanjing 210044, China; gsxingyang@163.com \\ 2 Gucheng Agro-Meteorological Field Scientific Experiment Base, Chinese Academy of Meteorological Sciences, \\ Beijing 100081, China; zhouhln@163.com \\ 3 Collaborative Innovation Center on Forecast Meteorological Disaster Warning and Assessment, \\ Nanjing University of Information Science \& Technology, Nanjing 210044, China \\ 4 Joint Eco-Meteorological Laboratory of Chinese Academy of Meteorological Sciences and Zhengzhou \\ University, Zhengzhou University, Zhengzhou 450001, China \\ 5 College of Resources and Environmental Sciences, China Agricultural University, Beijing 100193, China; \\ heqijin@cau.edu.cn \\ * Correspondence: zhougs@cma.gov.cn; Tel.: +86-010-62167890 or +86-136-2109-7075
}

Citation: Song, X.; Zhou, G.; He, Q.; Zhou, H. Quantitative Response of Maize Vcmax25 to Persistent Drought Stress at Different Growth Stages. Water 2021, 13, 1971. https:// doi.org/10.3390/w13141971

Academic Editor: Maria Mimikou

Received: 24 June 2021

Accepted: 16 July 2021

Published: 19 July 2021

Publisher's Note: MDPI stays neutral with regard to jurisdictional claims in published maps and institutional affiliations.

Copyright: (c) 2021 by the authors. Licensee MDPI, Basel, Switzerland. This article is an open access article distributed under the terms and conditions of the Creative Commons Attribution (CC BY) license (https:// creativecommons.org/licenses/by/ $4.0 /)$.

\begin{abstract}
Drought stress has adverse effects on crop growth and yield, and its identification and monitoring play vital roles in precision crop water management. Accurately evaluating the effect of drought stress on crop photosynthetic capacity can provide a basis for decisions related to crop drought stress identification and monitoring as well as drought stress resistance and avoidance. In this study, the effects of different degrees of persistent drought in different growth stages (3rd leaf stage, 7 th leaf stage and jointing stage) on the maximum carboxylation rate at a reference temperature of $25^{\circ} \mathrm{C}(\mathrm{Vcmax} 25)$ of the first fully expanded leaf and its relationship to the leaf water content (LWC) were studied in a field experiment from 2013 to 2015. The results indicated that the LWC decreased continuously as drought stress continued and that the LWC decreased faster in the treatment with more irrigation. Vcmax25 showed a decreasing trend as the drought progressed but had no clear relationship to the growth stage in which the persistent drought occurred. Vcmax25 showed a significantly parabolic relationship $\left(\mathrm{R}^{2}=0.701, p<0.001\right)$ with the LWC, but the different degrees of persistent drought stress occurring in different growth stages had no distinct effect on the LWC values when Vcmax25 reached its maximum value or zero. The findings of this study also suggested that the LWC was $82.5 \pm 0.5 \%$ when $V_{c m a x} 25$ reached its maximum value $\left(42.6 \pm 3.6 \mu \mathrm{mol} \mathrm{m}^{-2} \mathrm{~s}^{-1}\right)$ and $67.6 \pm 1.2 \%$ (extreme drought) when Vcmax 25 reached zero. These findings will help to improve crop drought management and will be an important reference for crop drought identification, classification and monitoring as well as for the development of drought monitoring and early warning systems for other crops or maize varieties.
\end{abstract}

Keywords: maize; Vcmax25; persistent drought; leaf water content; quantitative relationship

\section{Introduction}

Owing to the rise in water demand and looming climate change, plant drought stress has become a major research focus in recent years [1]. As one of the major abiotic environmental factors limiting plant growth, drought is best characterized by a series of its properties, such as its frequency, duration, and range of influence [2,3]. Droughts occur in virtually all climatic zones, including humid regions $[4,5]$. In recent years, large-scale intensive droughts have occurred on all continents, affecting most areas of the world [6,7]. China is a frequently drought-affected country [8]. In China, the monthly, annual and inter-annual variations in precipitation and temperature are significant, which causes frequent occurrences of drought [9]. The devastating impacts of droughts in China have 
attracted much attention, as the reported agricultural drought-inducible disaster area has shown an increasing trend in China. Since the 1950s, the grain yield losses from drought have increased from $2.5 \times 10^{11}$ to $3 \times 10^{11} \mathrm{~kg}$, accounting for $60 \%$ of all crop losses due to natural disasters [10]. Notably, the duration and intensity of drought are predicted to increase over the next decades under climate change, which would seriously affect China's agricultural production [11,12].

Maize, wheat and rice are considered the three major staple crops grown for global human consumption, livestock feed and raw materials for industrial purposes $[13,14]$. Currently, drought stress is a crucial limitation on maize production, resulting in yield decreases of 25-30\% and even leading to complete crop losses in extreme drought years [15]. Water stress limits maize growth and yield mainly due to reductions in its carbon-water balance [16-18], which is largely dependent on photosynthesis [19,20]. Generally, reductions in plant photosynthesis caused by drought are caused by stomatal limitation (SL) and nonstomatal limitation (NSL). Under mild and moderate drought stress, SL is the main factor causing crop photosynthesis reduction. As drought continues, NSL processes related to the inhibition of plant photosynthesis develop and limit the photosynthetic capacity of the plant $[21,22]$. The maximum carboxylation rate at a reference temperature of $25^{\circ} \mathrm{C}(\mathrm{Vcmax} 25)$ is an important parameter used to characterize the crop photosynthetic capacity $[23,24]$. Vcmax 25 is known to vary substantially in response to environmental controls, especially water stress, which has a large effect on Vcmax25 [25,26]. Thus far, most relevant literature has focused on the effect of soil water content on Vcmax25 [27-30]. However, the relationships between photosynthetic capacity (Vcmax25) and leaf water content (LWC) have received less attention [31]. Leaves are the most important organ for plant photosynthesis, and their water content is the best indicator of plant water deficit levels [32]. LWC is a comprehensive reflection of air dryness, soil water supply capacity, and crop drought tolerance [33]. Compared with the soil water content, LWC can more directly reflect the actual growth and development state of crops and is easy to observe, thus playing an irreplaceable role in drought monitoring and early warning systems [34,35].

Plant physiological processes are highly sensitive to water stress, especially that related to the plant organ water state [36]. Generally, crop photosynthetic characteristics have been taken as critical indicators of plant growth since they are directly related to net productivity [37]. Vcmax25 represents the crop's photosynthetic capacity in terms of the photosynthetic process, and LWC is an optimal ecological indicator to reflect the crop's water status. It can provide the basis for the determination of crop drought degrees and the formulation of irrigation measurements [32,38]. Thus, the relationship between Vcmax25 and LWC is an essential component in improving crop drought identification in order to cope with climate change.

Leaves at different positions respond differently to water stress due to the differences in their age, growth and developmental status, and functional traits [39]. In our previous study, we determined the LWC when maize photosynthesis in leaves at different positions changed from being determined by SL to being determined by NSL, and the LWC of the first fully expanded leaf was determined to be the optimal indicator of water stress in maize [40]. As drought progresses, the photosynthetic capacity of maize can become limited. Thus, in the current study, the effect of different drought stresses in different growth stages on Vcmax25 and its relationship to the LWC of the first fully expanded leaf were studied based on data from a field experiment performed from 2013 to 2015. Our aims were to (1) explore the responses of maize Vcmax25 to different degrees of water stress in different growth stages, (2) examine the relationship between the maize Vcmax25 and the LWC, and (3) determine the LWC when the maize Vcmax25 reached its maximum value and zero. Our hypotheses are as follows: (1) Vcmax25 responds differently to drought stress in different growth stages, and there exists a threshold response of Vcmax25 to LWC and (2) persistent drought occurring at different growth stages has little effect on the LWC value when the Vcmax25 reaches a maximum value and zero. We believe that the findings of this study will provide a basis for the classification of drought disasters as 
well as for the development of early warning systems and drought monitoring systems for maize cultivation.

\section{Materials and Methods}

\subsection{Climate and Soil Characteristics}

The experiment was conducted at the Gucheng Experimental Station of Ecological and Agricultural Meteorology $\left(39^{\circ} 08^{\prime} \mathrm{N}, 115^{\circ} 40^{\prime}\right.$ E, altitude: $\left.15.2 \mathrm{~m}\right)$ of the China Meteorological Administration from 2013 to 2015. The experimental station is located in Baoding, Hebei province, with a warm temperate continental monsoon climate. The annual average air temperature is $12.2^{\circ} \mathrm{C}$ and the annual average precipitation is $528 \mathrm{~mm}$, of which $70 \%$ occurs from June to September. The annual average sunshine time is $3364 \mathrm{~h}$, and the average frost-free period is $185 \mathrm{~d}$. The experimental terrain was flat, with a sandy loam soil. The average bulk density of $0-30 \mathrm{~cm}$ soil was $1.37 \mathrm{~g} \mathrm{~cm}^{-3}$, the field capacity (i.e., the maximum water content that the soil can maintain) was $22.7 \%$, and the permanent wilting point was $6.7 \%$. The fertility status of the experimental soil is shown in Table 1 . The main local food crops are winter wheat and summer maize. Summer maize is sown in June and harvested in October.

Table 1. Physical and chemical properties of soil profiles in the experimental plots.

\begin{tabular}{|c|c|c|c|c|c|c|c|c|c|}
\hline $\begin{array}{l}\text { Depth } \\
\text { cm }\end{array}$ & $\begin{array}{l}\text { Total N } \\
\mathrm{g} \mathrm{kg}^{-1}\end{array}$ & $\begin{array}{l}\text { Total P } \\
\mathrm{g} \mathrm{kg}^{-1}\end{array}$ & $\begin{array}{l}\text { Total K } \\
\mathrm{g} \mathrm{kg}^{-1}\end{array}$ & $\begin{array}{c}\text { Organic } \\
\text { Matter } \\
\mathrm{g} \mathrm{kg}^{-1}\end{array}$ & $\begin{array}{c}\text { Available } \\
\text { P } \\
\mathrm{mg} \mathrm{kg}^{-1}\end{array}$ & $\begin{array}{c}\text { Available } \\
\text { K } \\
\text { mg kg }^{-1}\end{array}$ & $\mathrm{pH}$ & $\begin{array}{c}\text { Bulk } \\
\text { Density } \\
\mathrm{g} \mathrm{cm}^{-3}\end{array}$ & $\begin{array}{c}\text { Field } \\
\text { Capacity } \\
\%\end{array}$ \\
\hline $0-30$ & 0.9753 & 1.0196 & 17.2624 & 13.67 & 25.76 & 118.55 & 8.2 & 1.37 & 22.7 \\
\hline
\end{tabular}

\subsection{Experimental Design}

The maize cultivar used in this experiment was Zheng Dan 958 with a height of $246 \mathrm{~cm}$ and a potential yield of $8805 \mathrm{~kg} \mathrm{ha}^{-1}$, which is commonly planted across northern China. There were six treatments in 2013 and 2014, and two treatments in 2015. The experimental plots were randomly arranged with three replicates per treatment. Water control began in 2013 from the 7th leaf stage (24 July), with one-time irrigation on 24 July, with D1-D6 treatments of irrigation at 100, 80,60,40,25, and $15 \mathrm{~mm}$, respectively. Water control began in 2014 from the 3rd leaf stage (2 July) and a single irrigation was carried out on 2 July, with the D1-D6 treatments receiving 150, 120, 90, 60, 30, and $10 \mathrm{~mm}$, respectively. Water was controlled from the jointing stage in 2015 (10 August). A single irrigation was carried out on 10 August, with the D1 and D2 treatment receiving irrigation of 16 and $0 \mathrm{~mm}$, respectively. Before water control, each treatment maintained normal irrigation to ensure seedling emergence and normal growth. In 2015, there were only two treatments and these were used to analyze the relationship between photosynthetic capacity and LWC.

\subsection{Field Management}

The experimental plots covered an area of $8 \mathrm{~m}^{2}(4 \mathrm{~m} \times 2 \mathrm{~m})$. The plots were separated by a $3 \mathrm{~m}$ deep concrete wall to prevent the horizontal exchange of soil moisture. A large electric rain-proof shed above the experimental plot was used to shield the natural precipitation to carry out water control. The maize was sowed after wheat harvesting, the sowing dates for 2013, 2014 and 2015 were 27 June, 24 June and 25 June, respectively. Fertilizer application was carried out at the time of sowing, and there was no topdressing during the experiment. The fertilization amount (diammonium phosphate, a compound fertilizer, $\left.300 \mathrm{~kg} \mathrm{ha}^{-1}\right)$ and the planting density $\left(7\right.$ plants $\left.\mathrm{m}^{-2}\right)$ were consistent with local fields. 


\subsection{Sampling and Measurements}

\subsubsection{Leaf Gas Exchange}

The observation of leaf gas exchange parameters was carried out at 9:30-11:30 on a clear cloudless day. The first leaf was completely expanded at the top, and three healthy maize plants with the same growth vigor were selected for the determination of leaf photosynthesis in each treatment. The determination site was the middle upper part of the leaf, avoiding the central leaf vein. Three replicates were taken for each treatment at intervals of 7-10 days and measurements were added at the critical maize growth stages. The LI-6400 portable photosynthesis system (Li-6400; LI-COR Inc., Lincoln, NE, USA) was used to determine the maize leaf photosynthetic rate $\left(\mathrm{A}_{\mathrm{n}}, \mu \mathrm{mol} \mathrm{m} \mathrm{m}^{-2} \mathrm{~s}^{-1}\right)$, leaf temperature $\left(\mathrm{Tl},{ }^{\circ} \mathrm{C}\right)$ and environmental factors. The photosynthetically active radiation (PAR) in the leaf chamber was set to $1500 \mu \mathrm{mol} \mathrm{m}{ }^{-2} \mathrm{~s}^{-1}$, which was the saturated light intensity of maize. During the measurement periods, the temperature, relative humidity and $\mathrm{CO}_{2}$ concentration inside the leaf chamber were consistent with ambient air values, and the flow rate was set to $500 \mu \mathrm{mol} \mathrm{s}^{-1}$.

\subsubsection{Leaf Water Content}

Leaves were sampled after the observation of photosynthetic physiological parameters at 9:00 a.m.-11:00 a.m., and the leaf samples were consistent with those observed by photosynthesis. Three replicates were taken for each treatment at intervals of 7-10 days and measurements were added at the critical maize growth stages. The leaves were separated from the plants by scissors. The fresh weight was measured and then the leaves were put into a paper bag, then put into the oven for $105^{\circ} \mathrm{C}$ deactivation for $1 \mathrm{~h}$, then dried to constant weight at $80^{\circ} \mathrm{C}$ to determine the dry weight. The LWC was calculated by the following equation:

$$
\text { Leaf water content }(\text { LWC })=\frac{\text { leaf fresh weight }- \text { leaf dry weight }}{\text { leaf fresh weight }} \times 100
$$

\subsubsection{Maximum Carboxylation Rate at $25^{\circ} \mathrm{C}(\mathrm{Vcmax} 25)$}

Farquhar et al. [41] proposed a $C_{3}$ plant photosynthetic biochemical mechanism model, and Von Caemmerer [42] applied the model to $\mathrm{C}_{4}$ plants. It was considered that the leaf photosynthetic rate $\left(A_{n}, \mu \mathrm{mol} \mathrm{m}{ }^{-2} \mathrm{~s}^{-1}\right)$ was mainly limited by Rubisco enzyme activity, expressed as:

$$
A_{n}=\frac{V_{c \max } C}{C+k_{c}\left(1+O / k_{0}\right)}\left(1-\frac{\gamma^{*} O}{C}\right)-R_{d}
$$

Massad et al. [43] applied the $C_{4}$ plant photosynthesis model to maize and pointed out that, the photosynthesis of the Rubisco enzyme activity limit in $\mathrm{C}_{4}$ plants was more sensitive to the temperature than in $C_{3}$ plants under the saturated light intensity conditions. In the $C_{4}$ plants, Vcmax was more sensitive to temperature but less sensitive to Kc and Ko. Therefore, the reduction of enzyme activity at high temperature was taken into consideration on the basis of the Arrhenius equation, and the temperature correction function of Vcmax was given as follows:

$$
\mathrm{f}\left(T_{k}\right)=\exp \left[\frac{E_{a}\left(T_{k}-298\right)}{\left(298 R T_{k}\right)}\right] \frac{1+\exp \left(\frac{298 \Delta S-H_{d}}{298 R}\right)}{1+\exp \left(\frac{T_{k} \Delta S-H_{d}}{T_{k} R}\right)}
$$

which can obtain:

$$
\operatorname{Vcmax} 25=\frac{A_{n}}{\left[\frac{C}{C+k_{c}\left(1+\frac{O}{k_{0}}\right)}\left(1-\frac{\gamma^{*} O}{C}\right)-0.01\right] \exp \left[\frac{E_{a}\left(T_{k}-298\right)}{\left(298 R T_{k}\right)}\right] \frac{1+\exp \left(\frac{298 \Delta S-H_{d}}{298 R}\right)}{1+\exp \left(\frac{T_{k} \Delta S-H_{d}}{T_{k} R}\right)}}
$$


The explanations for values and meaning of the parameters in Equations (2)-(4) are shown in Table 2. The Li-6400 fluorescent leaf chamber was used to observe the photosynthetic physiological parameters of leaves. The light intensity was set at $1500 \mu \mathrm{mol} \mathrm{m}{ }^{-2} \mathrm{~s}^{-1}$, and the temperature, humidity, and $\mathrm{CO}_{2}$ concentration were all consistent with outside environmental conditions. Maize is a $\mathrm{C}_{4}$ plant. Under saturated light intensity, temperature is an important environmental factor affecting leaf physiological parameters. According to Equation (4), the temperature is modified to obtain the Vcmax at $25^{\circ} \mathrm{C}(\mathrm{Vcmax} 25)$.

Table 2. Summary of $\mathrm{C}_{4}$ photosynthesis model parameters at $25^{\circ} \mathrm{C}$.

\begin{tabular}{ccc}
\hline Parameter & Description & Value \\
\hline$A_{n}\left(\mu \mathrm{molm}^{-2} \mathrm{~s}^{-1}\right)$ & Net photosynthetic rate & Actually measure \\
$R_{d}\left(\mu \mathrm{molm}^{-2} \mathrm{~s}^{-1}\right)$ & Leaf mitochondrial respiration & 0.01 Vcmax \\
$\mathrm{C}(\mu \mathrm{bar})$ & $\mathrm{CO}_{2}$ concentration in the bundle sheath & $\mathrm{CO}_{2}$ concentation in reference room \\
$\mathrm{O}(\mathrm{mbar})$ & Partial pressure of $\mathrm{O}_{2}$ & 210 \\
$\gamma^{*}(\mathrm{bar} / \mathrm{bar})$ & Half the reciprocal of Rubisco specificity & 0.000193 \\
$V_{c \text { max }}\left(\mu \mathrm{molm} \mathrm{m}^{-2} \mathrm{~s}^{-1}\right)$ & Maximum carboxylation rate & $/$ \\
$K_{c}(\mu \mathrm{bar})$ & Michaelis-Menten constant of Rubisco for $\mathrm{CO}_{2}$ & 650 \\
$K_{o}(\mathrm{mbar})$ & Michaelis-Menten constant of Rubisco for $\mathrm{O}_{2}$ & 450 \\
$f\left(T_{k}\right)$ & Temperature correction function & $/$ \\
$T_{k}(\mathrm{~K})$ & Leaf temperature & Actually measure \\
$E_{a}\left(\mathrm{kJmol}^{-1}\right)$ & Activation energy & 58.52 \\
$R\left(\mathrm{JK}^{-1} \mathrm{~mol}^{-1}\right)$ & Gas constant & 8.31 \\
$\Delta S\left(\mathrm{JK}^{-1} \mathrm{~mol}^{-1}\right)$ & Entropy term & 710 \\
$H_{d}\left(\mathrm{KJmol}^{-1}\right)$ & Deactivation energy & 220
\end{tabular}

\subsection{Statistical Analyses}

SPSS v.21.0 (SPSS Inc., Chicago, IL, USA) was used for variance analysis, and the Duncan method was used for multiple comparisons of variance analysis $(p<0.05)$. Data fitting and graphical presentation were carried out in Origin Pro 2016 (Origin Lab, Northampton, MA, USA). Polynomial fitting was used for the regression analyses.

\section{Results}

\subsection{Leaf Water Content Changes with Drought Development}

Figure 1 shows the changes in the LWC of the first fully expanded leaf of maize in different growth periods and under different drought intensities. The LWC decreased greatly at the beginning of the drought period and then decreased gradually with drought development. The LWC decreased slowly as the growth period continued. In 2013 and 2014, the extent of the decrease in the LWC of maize at 33 and 64 days after water control began to slow. In 2013, during the rapid decrease period, the LWC of maize under the D1-D6 treatments decreased at rates of $0.43 \%, 0.46 \%, 0.37 \%, 0.30 \%, 0.23 \%$, and $0.26 \% \mathrm{~d}^{-1}$, respectively. In 2014, during the rapid decrease period, the LWC of maize in the D1-D6 treatments decreased at rates of $0.34 \%, 0.29 \%, 0.32 \%, 0.30 \%, 0.26 \%$, and $0.30 \% \mathrm{~d}^{-1}$, respectively. The LWC for the treatment with more irrigation decreased at higher rates. 

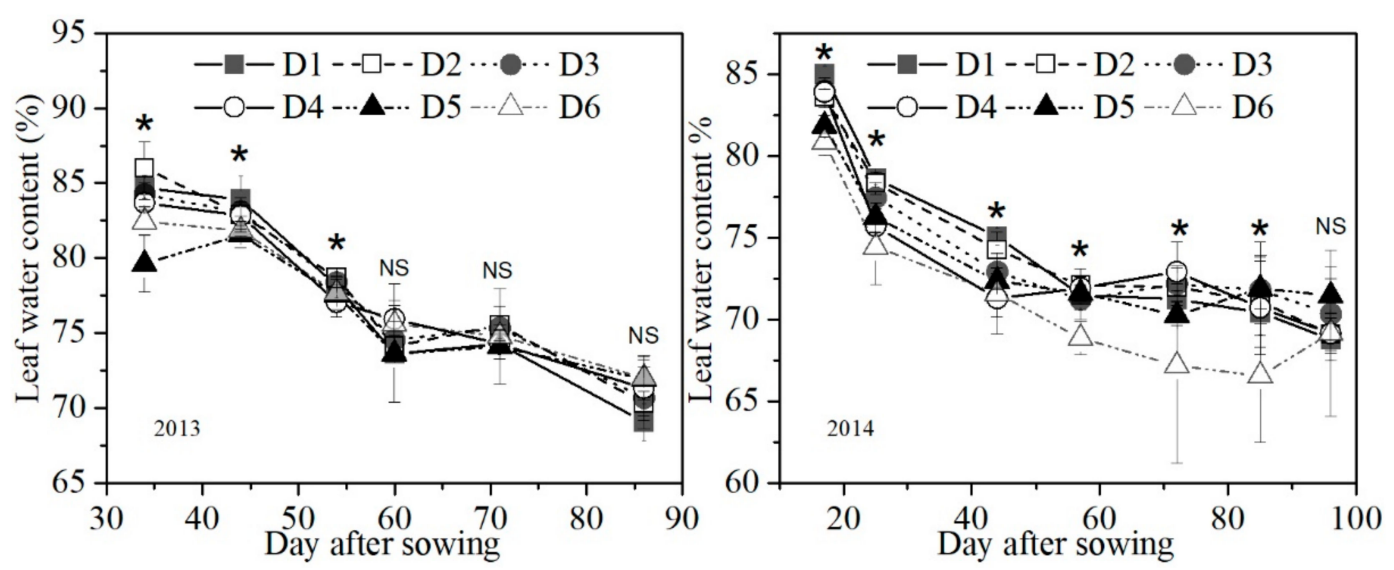

Figure 1. Leaf water content (LWC) changes with the development process of drought during 2013 and 2014. Note: *, significant differences at the $5 \%$ level were found in various treatments; NS, significant differences at the 5\% level were not found in various treatments.

There were significant differences in LWC values among the different treatments after water control began. The differences in LWC among the different treatments decreased gradually as the growth period continued. There were significant differences in LWC among the different treatments the 7 days after water control in 2013. The LWCs of the higher irrigation treatments (D1-D4) were significantly higher than those of the lower irrigation treatments (D5 and D6), but there were no significant differences among the different treatments 33 days after the water control began $(p<0.05)$. There were significant differences in LWC among the different treatments at 9 days after water control began in 2014. The LWC of the D1 treatment was significantly higher than that of the D2 treatment, and the LWC of the D2-D4 treatments was significantly higher than that of the D5 and D6 treatments. The difference in LWC among the different treatments decreased gradually 49 days after water control began; the differences in LWC among the D1-D5 treatments were not significant, but the LWCs in the D1-D5 treatments were significantly higher than that in the D6 treatment $(p<0.05)$, which had the least irrigation. There were no significant differences in LWC among the different treatments 88 days after water control began. As the drought progressed, the soil water content decreased gradually, and the leaves could not absorb enough water from the soil for photosynthesis or organic matter accumulation. Moreover, the leaves needed to maintain a certain amount of water to maintain their own growth. At the later stages of water control, the maize LWC reached the minimum value that could maintain leaf growth, leading to the absence of significant differences among treatments.

\subsection{Vcmax25 Changes with Drought Development}

The maximum carboxylation rate at a reference temperature of $25^{\circ} \mathrm{C}(\mathrm{Vcmax} 25)$ of the first fully expanded leaf of maize under the different drought intensity stresses in different growth periods changed with the growth period, as shown in Figure 2. As the drought progressed, the photosynthetic capacity of maize decreased overall. The Vcmax25 of the D1 and D2 treatments increased slightly 17 days after water control in 2013, then decreased rapidly and gradually decreased more slowly at 33 days after water control. In 2014, Vcmax25 reached a maximum value the 9 days after water control and then started to decrease. Vcmax25 decreased rapidly 7-36 days after water control. The Vcmax25 decrease gradually slowed at 36 days after water control. In 2013, the Vcmax25 of the D1-D6 treatments reached the maximum value 17 days after water control, at values of $56.9,50.3,47.3,46.4,46.9$, and $45.5 \mu \mathrm{mol} \mathrm{m}{ }^{-2} \mathrm{~s}^{-1}$, respectively. The $V_{c m a x} 25$ values of the D1 and D2 treatments (higher irrigation) were distinctly higher than those of the D3-D6 treatments (lower irrigation). In 2014, the Vcmax25 of the D1-D6 treatments reached the maximum value 9 days after water control, at values of 40.6, 47.4, 48.5, 42.7, 41.0, and 
$37.4 \mu \mathrm{mol} \mathrm{m}{ }^{-2} \mathrm{~s}^{-1}$, respectively, and there were distinct differences among the treatments with regard to when the Vcmax 25 reached the maximum value.
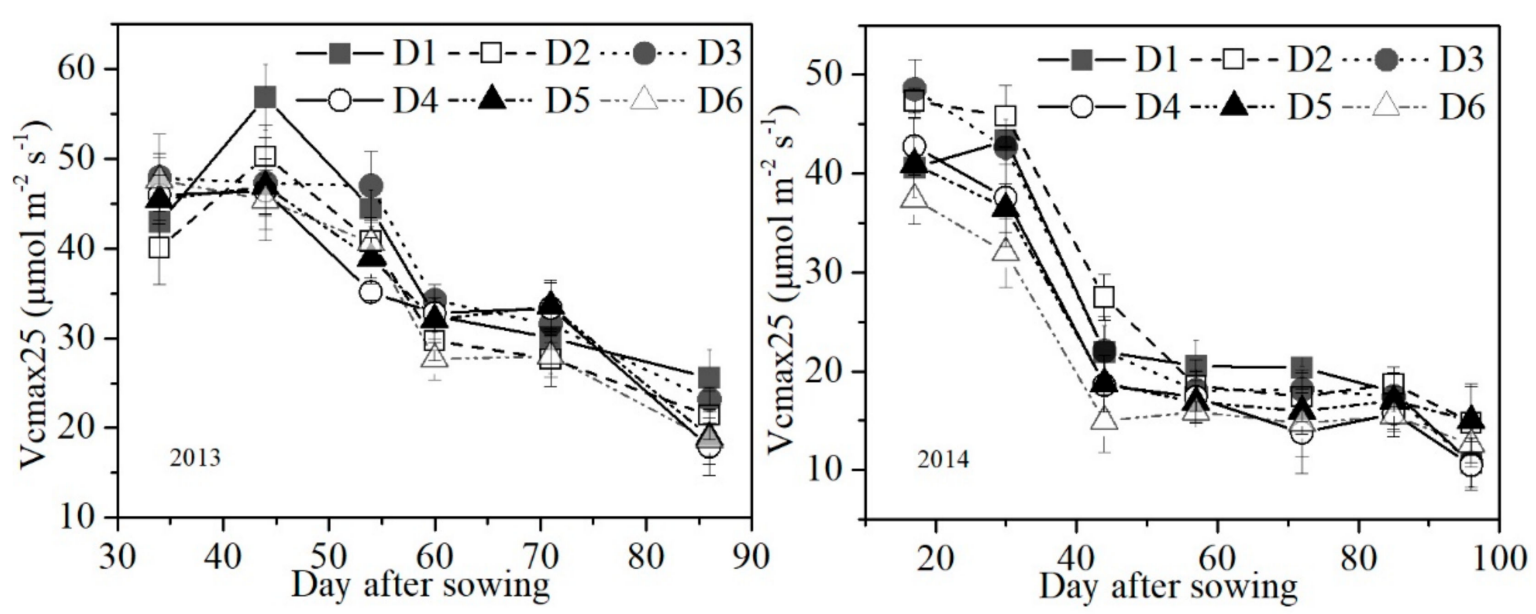

Figure 2. Vcmax25 changes with the development process of drought during 2013 and 2014.

\subsection{Relationship between Vcmax 25 and LWC in Maize}

Photosynthesis is the basis of crop growth and development. Vcmax 25 can strongly reflect the photosynthetic capacity of plants. In this study, the relationship between Vcmax25 and LWC was analyzed, and we found that there was a significant quadratic relationship between Vcmax25 and LWC (Figures S1-S3, Table S1). A detailed analysis of the LWC thresholds for the various treatments in 2013, 2014 and 2015 can be found in the Supplementary data.

The differences in LWC when $\mathrm{V}_{c}$ max 25 reached threshold (maximum and minimum) values among the different treatments were not obvious, and the effect of different degrees of persistent drought on Vcmax 25 was not obvious (Supplementary data); thus, all treatments in each year were analyzed (Figure 3; Table 3). The results showed that in 2013, 2014 and 2015, at LWC levels of $82.8 \%, 82.8 \%$ and 81.9\%, respectively, Vcmax25 reached maximum values of 46.1, 42.7 and $39.0 \mu \mathrm{mol} \mathrm{m}^{-2} \mathrm{~s}^{-1}$, respectively. Under drought conditions, at LWC values of $66.9 \%, 66.9 \%$ and $68.9 \%$ for 2013, 2014 and 2015, respectively, Vcmax25 decreased to zero.
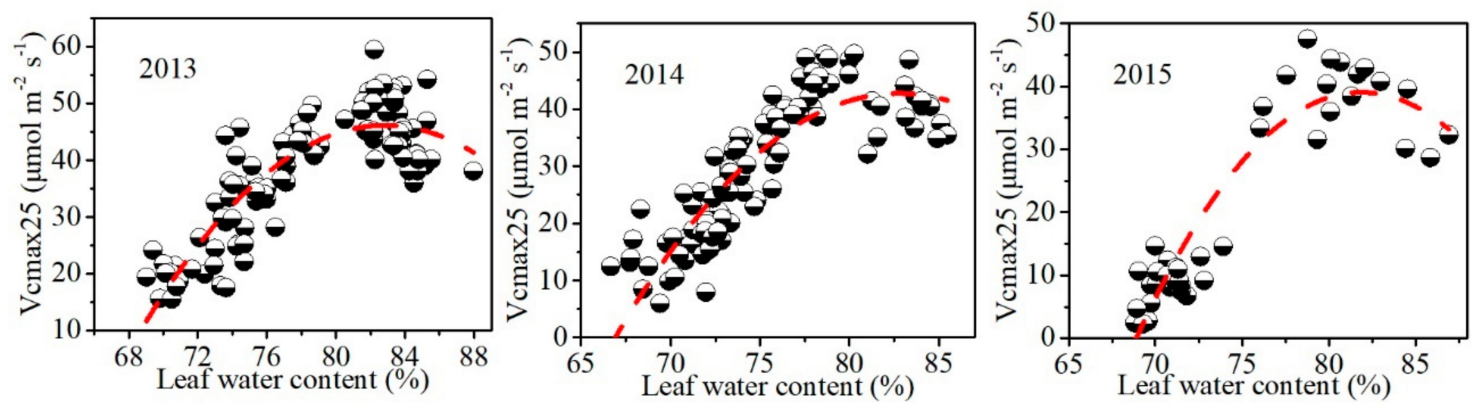

Figure 3. Relationship between LWC and Vcmax25 in 2013, 2014 and 2015. 
Table 3. Regression equation between leaf water content and Vcmax25 in 2013, 2014 and 2015.

\begin{tabular}{ccc}
\hline Treatments & Regression Equation & $\mathbf{R}^{\mathbf{2}}$ \\
\hline 2013 & $\mathrm{y}=-0.18058 \mathrm{x}^{2}+29.91681 \mathrm{x}-1192.92662$ & $0.786^{* * *}$ \\
2014 & $\mathrm{y}=-0.17019 \mathrm{x}^{2}+28.16861 \mathrm{x}-1122.81727$ & $0.761^{* * *}$ \\
2015 & $\mathrm{y}=-0.23199 \mathrm{x}^{2}+37.98876 \mathrm{x}-1516.08477$ & $0.879^{* * *}$ \\
all & $\mathrm{y}=-0.2189 \mathrm{x}^{2}+35.81634 \mathrm{x}-1418.92996$ & $0.701^{* * *}$ \\
\hline
\end{tabular}

*** means the leaf water content and Vcmax 25 were significantly related at a 0.001 significant level.

Significant differences in the LWC when Vcmax25 reached a maximum were not found among 2013, 2014 and 2015 (Table 4; $p<0.05$ ), which indicated that the LWC when Vcmax 25 reached a maximum value was not greatly affected by the occurrence of persistent drought stress in different growth periods. The results of this 3-year experiment (Figure 4, Table 3) indicated that when the LWC was $67.3 \%$, Vcmax 25 decreased to zero, and when the LWC was $81.8 \%$, Vcmax 25 reached a maximum value of $46.1 \mu \mathrm{mol} \mathrm{m}^{-2} \mathrm{~s}^{-1}$.

Table 4. The difference in LWC (\%) when Vcmax25 reached threshold between experiment years.

\begin{tabular}{ccc}
\hline & LWC of Vcmax25 Was Maximum & LWC of Vcmax25 Was Zero \\
\hline 2013 & $82.5 \mathrm{a}$ & $66.9 \mathrm{~b}$ \\
2014 & $81.6 \mathrm{a}$ & $67.6 \mathrm{ab}$ \\
2015 & $84.0 \mathrm{a}$ & $69.1 \mathrm{a}$ \\
\hline
\end{tabular}

Means within a column followed by the same letters are not significantly different at a 0.05 significant level (Duncan's one-way ANOVA).

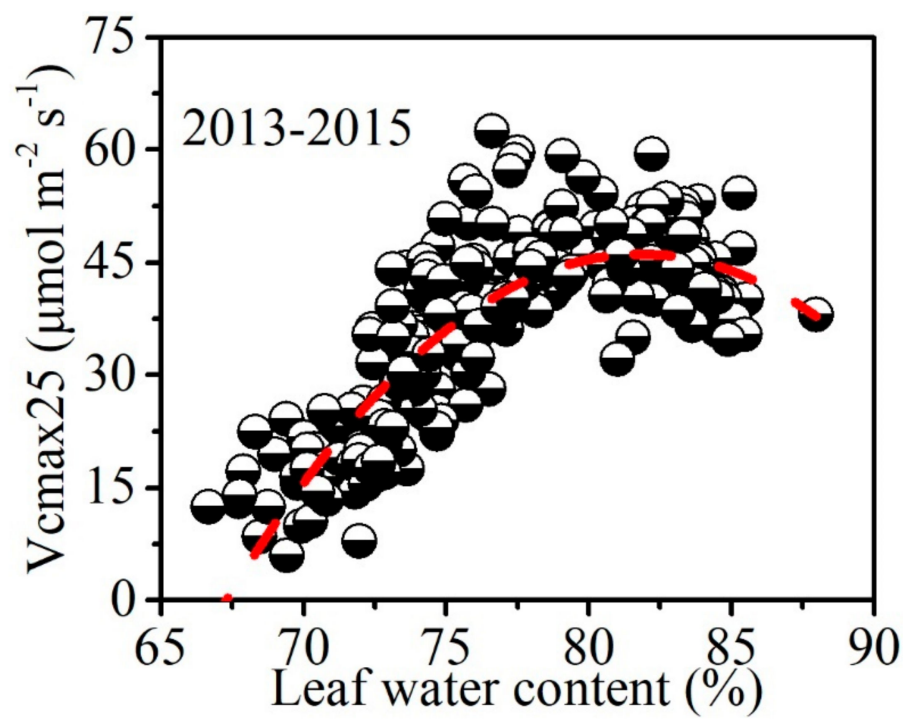

Figure 4. Relationship between LWC and Vcmax25 during 2013-2015.

\section{Discussion}

It is generally assumed that drought-induced decreases in photosynthesis are due primarily to stomatal closure, which decreases $\mathrm{CO}_{2}$ availability in the mesophyll, rather than to a direct effect on the capacity of the photosynthetic apparatus [21,44,45]. As drought progresses, the photosynthetic capacity of plants will be limited by drought. Vcmax25 is an important parameter for measuring crop photosynthetic capacity, which is of great importance to plant photosynthesis and gas exchange [26,46]. Water deficit is considered to be the main environmental factor limiting Vcmax25 [47]. In dry seasons, $V_{c}$ cmax 25 decreases with decreasing soil moisture, and soil moisture can explain $61 \%-64 \%$ of the variation in Vcmax25 [27]. Our results showed that the maize Vcmax 25 decreased gradually under persistent drought occurring in different growth stages and that water stress had a distinct effect on Vcmax25. Sufficient water can facilitate the supply of soil elements, 
increase the stomatal conductance of leaves and increase intercellular $\mathrm{CO}_{2}$ concentrations, thereby improving the photosynthetic capacity of crops [48-50]. In contrast, water deficit will close the stomata and limit the entry of $\mathrm{CO}_{2}$ into the cells [19], thus reducing Vcmax25; a lack of water also affects the expression of genes related to carboxylation and slows carboxylase synthesis, thereby reducing the carboxylation rate [51,52]. Cai et al. [53] found that the Vcmax25 of maize decreased significantly with increasing drought stress. The $\mathrm{V}$ cmax 25 of Leymus chinensis showed a parabolic relationship with the increase in soil water content [54]. In this study, the relationship between LWC and Vcmax25 was studied, and similar results were obtained, i.e., maize $\mathrm{Vcmax} 25$ changed in a parabolic pattern with increasing LWC.

Vcmax25 exhibits a significant threshold response to water stress [28], and the accurate identification of this threshold is significant for crop drought identification, assessment, and classification. Leaves, as the most important photosynthetic organ in plants, are intimately associated with plant functions and adaptation to environmental changes. The LWC is an important index of leaf water conservation, as well as the most sensitive index to drought stress. The maize LWC decreases gradually during persistent reductions in the field water capacity from $75 \%$ to $25 \%$ [45]. Our results showed that with the development of drought, LWC gradually decreased. Dynamic changes in LWC can directly reflect the degree of drought stress in maize, which is attributed to the fact that plant organ water content variations in response to drought can be used to determine the relationship between plant water content and soil moisture and play vital roles in evaluating drought impact [55]. Optimal water conditions are good for maize growth and lead to high LWC consumption; this led to the LWC decreasing faster in the treatments with more irrigation in this study. The LWC has a significant relationship with photosynthesis, and soil drought first leads to decreases in the LWC, which reduces the photosynthesis rate and influences dry matter partitioning among organs [56]. The LWC can be used to indicate whether the crop's photosynthetic capacity is limited by drought stress. Available soil water content of $39.3-44.1 \%$ is the photosynthesis rate threshold for maize [57], and a decrease in wheat LWC from $75 \%$ to $70 \%$ is an important turning point for leaf photosynthetic physiological activity [58]. In this study, when the LWC was $67.6 \pm 1.2 \%$, Vcmax25 decreased to zero, and when the LWC was $82.5 \pm 0.5 \%$, Vcmax25 reached the maximum value $\left(42.6 \pm 3.6 \mu \mathrm{mol} \mathrm{m} \mathrm{m}^{-2} \mathrm{~s}^{-1}\right)$, these results confirmed our hypothesis that there exists a threshold response of $\mathrm{Vcm}_{\mathrm{c}} \mathrm{x} 25$ to LWC. When the LWC is less than $70 \%$, the structure and function of the photosynthetic organs of maize are destroyed, and carboxylase synthesis is blocked, causing Vcmax25 to finally decrease to zero [58]. The results of this study also showed that persistent drought in the different growth stages had little effect on the value of the LWC when Vcmax25 was at a maximum. Vcmax25 is the representation of plant photosynthetic capacity and is mainly affected by water stress. The time of drought occurrence had no obvious effects on the value of the LWC when Vcmax25 was at a maximum, which is consistent with our hypotheses.

In our previous study, the LWC when maize photosynthesis changed from being determined by SL to NSL was $75.5 \pm 1.5 \%-75.7 \pm 1.3 \%$ [40]. In the current study, the relationship between the first fully expanded leaf $\mathrm{Vcmax}_{\mathrm{c}} 5$ and the LWC of maize was quantitatively studied, and the LWC was $67.6 \pm 1.2 \%$ when Vcmax 25 decreased to zero. This result indicated that the reduction in maize photosynthesis was caused by NSL factors, which led to a reduction in maize photosynthetic capacity. Taken together, these results provide a critical reference for crop drought disaster identification, classification and monitoring through remote sensing. Quantifying the correlation between LWC and plant physiological response processes, especially the relationship between leaf photosynthetic processes and the plant water status, will be useful in determining plant ecological adaptability and appropriate crop water management strategies $[59,60]$. The current study addressed the lack of knowledge of this relationship by quantitatively studying the relationship between Vcmax25 and LWC. The relationship between Vcmax25 and LWC in different vegetation types should be studied in future research to provide information for vegetation drought 
monitoring and early warning systems worldwide. In addition, a relationship model between LWC and canopy water content should be developed to improve the accuracy of global drought monitoring. Our findings may provide new insight into crop drought classification and monitoring. These insights could be extended to other staple crops, such as wheat and rice, in order to more deeply understand the relationship between the physiological processes involved in plant photosynthesis and relevant ecological indicators and to lay a foundation for the establishment of optimal evaluation indicators for crop drought identification and early warning systems.

\section{Conclusions}

The present study indicated that as the drought continued, the LWC and Vcmax25 decreased continuously; LWC decreased with the increase in water stress and decreased faster in the treatment with more irrigation. There was a parabolic relationship between maize photosynthetic capacity and LWC; as LWC increased, the photosynthetic capacity initially increased and then decreased. The occurrence of persistent drought in different growth periods had little effect on the LWC threshold value when Vcmax25 was zero or at its maximum. The LWC was $67.6 \pm 1.2 \%$ when $V_{c}$ max 25 was zero and $82.5 \pm 0.5 \%$ when Vcmax25 was its maximum value of $42.6 \pm 3.6 \mu \mathrm{mol} \mathrm{m}^{-2} \mathrm{~s}^{-1}$.

Supplementary Materials: The following are available online at https:/ /www.mdpi.com/article/10 .3390/w13141971/s1, Figure S1: Relationship between LWC and Vcmax25 for various treatments in 2013, Figure S2: Relationship between LWC and Vcmax25 for various treatments in 2014, Figure S3: Relationship between LWC and Vcmax25 for various treatments in 2015, Table S1: Regression equation between leaf water content and Vcmax25 during 2013-2015.

Author Contributions: G.Z. and Q.H. conceived and designed the research, X.S. and H.Z. performed the experiment and analyzed the data, X.S. and G.Z. wrote the manuscript. All authors have read and agreed to the published version of the manuscript.

Funding: This work is financially supported by the National Key Research and Development Program of China (2018YFA0606103, 2016YFD0300106), National Natural Science Foundation of China (41705093), and China Special Fund for Meteorological Research in the Public Interest (No. GYHY201506019). We appreciate Ma Xueyan, Wang Qiuling, Feng Xiaoyu for their help in the field experiments and data collection.

Institutional Review Board Statement: Not applicable.

Informed Consent Statement: Not applicable.

Data Availability Statement: Data are contained with the article.

Acknowledgments: We appreciate Ma Xueyan, Wang Qiuling for their help in the field experiments and data collection.

Conflicts of Interest: The authors declare no conflict of interest.

\section{References}

1. Mishra, A.K.; Singh, V.P. A review of drought concepts. J. Hydrol. 2010, 391, 202-216. [CrossRef]

2. Chaves, M.M.; Marôco, J.; Pereira, J. Understanding plant responses to drought-From genes to the whole plant. Funct. Plant Biol. 2003, 30, 239-264. [CrossRef] [PubMed]

3. Sheffield, J.; Wood, E.; Roderick, M. Little change in global drought over the past 60 years. Nat. Cell Biol. 2012, 491, 435-438. [CrossRef] [PubMed]

4. Dai, A. Drought under global warming: A review. Wiley Interdiscip. Rev. Clim. Chang. 2011, 2, 45-65. [CrossRef]

5. Lai, C.; Zhong, R.; Wang, Z.; Wu, X.; Chen, X.; Wang, P.; Lian, Y. Monitoring hydrological drought using long-term satellite-based precipitation data. Sci. Total Environ. 2019, 649, 1198-1208. [CrossRef]

6. Park, S.; Im, J.; Jang, E.; Rhee, J. On Drought Assessment and Monitoring through Blending of Multi-sensor Indices Using Machine Learning Approaches for Different Climate Regions. Agric. For. Meteorol. 2016, 217, 157-169. [CrossRef]

7. Zhong, R.; Chen, X.; Lai, C.; Wang, Z; Lian, Y.; Yu, H.; Wu, X. Drought monitoring utility of satellite-based precipitation products across mainland China. J. Hydrol. 2019, 568, 343-359. [CrossRef]

8. Zou, X.; Zhai, P.; Zhang, Q. Variations in droughts over China: 1951-2003. Geophys. Res. Lett. 2005, 32, 353-368. [CrossRef] 
9. Jiang, R.; Xie, J.; He, H.; Luo, J.; Zhu, J. Use of four drought indices for evaluating drought characteristics under climate change in shaanxi, china: 1951-2012. Nat. Hazards 2015, 75, 2885-2903. [CrossRef]

10. Song, H.; Li, Y.; Zhou, L.; Xu, Z.; Zhou, G. Maize leaf functional responses to drought episode and rewatering. Agric. For. Meteorol. 2018, 249, 57-70. [CrossRef]

11. Leng, G.; Tang, Q.; Rayburg, S. Climate change impacts on meteorological, agricultural and hydrological droughts in China. Glob. Planet. Chang. 2015, 126, 23-34. [CrossRef]

12. Lu, W.; Ye, X.; Huang, J.; Horlu, G.S.A. Effect of climate change induced agricultural risk on land use in Chinese small farms: Implications for adaptation strategy. Ecol. Indic. 2020, 115, 1-10. [CrossRef]

13. Meng, Q.; Hou, P.; Wu, L.; Chen, X.; Cui, Z.; Zhang, F. Understanding production potentials and yield gaps in intensive maize production in China. Field Crop. Res. 2013, 143, 91-97. [CrossRef]

14. Ben-Ari, T.; Adrian, J.; Klein, T.; Calanca, P.; van der Velde, M.; Makowski, D. Identifying indicators for extreme wheat and maize yield losses. Agric. For. Meteorol. 2016, 220, 130-140. [CrossRef]

15. Thomas, D.S.G.; Twyman, C.; Osbahr, H.; Hewitson, B. Adaptation to climate change and variability: Farmer responses to intra-seasonal precipitation trends in South Africa. Clim. Chang. 2007, 83, 301-322. [CrossRef]

16. Xu, Z.Z.; Zhou, G.S.; Wang, Y.L.; Han, G.X.; Li, Y.J. Changes in Chlorophyll Fluorescence in Maize Plants with Imposed Rapid Dehydration at Different Leaf Ages. J. Plant Growth Regul. 2008, 27, 83-92. [CrossRef]

17. Bunce, J.A. Leaf Transpiration Efficiency of Some Drought-Resistant Maize Lines. Crop. Sci. 2010, 50, 1409-1413. [CrossRef]

18. Zhang, X.; Lei, L.; Lai, J.; Zhao, H.; Song, W. Effects of drought stress and water recovery on physiological responses and gene expression in maize seedlings. BMC Plant Biol. 2018, 18, 1-16. [CrossRef]

19. Flexas, J.; Bota, J.; Galmés, J.; Medrano, H.; Ribas-Carbo, M. Keeping a positive carbon balance under adverse conditions: Responses of photosynthesis and respiration to water stress. Physiol. Plant. 2006, 127, 343-352. [CrossRef]

20. Campos, H.; Trejo, C.; Peña-Valdivia, C.B.; García-Nava, R.; Conde-Martínez, F.V.; Cruz-Ortega, M. Stomatal and non-stomatal limitations of bell pepper (Capsicum annuиm L.) plants under water stress and re-watering: Delayed restoration of photosynthesis during recovery. Environ. Exp. Bot. 2014, 98, 56-64. [CrossRef]

21. Lawlor, D.W.; Cornic, G. Photosynthetic carbon assimilation and associated metabolism in relation to water deficits in higher plants. Plant Cell Environ. 2002, 25, 275-294. [CrossRef] [PubMed]

22. Flexas, J.; Barón, M.; Bota, J.; Ducruet, J.-M.; Gallé, A.; Galmés, J.; Jiménez, M.; Pou, A.; Ribas-Carbó, M.; Sajnani, C.; et al. Photosynthesis limitations during water stress acclimation and recovery in the drought-adapted Vitis hybrid Richter-110 (V. berlandieri $\times$ V. rupestris). J. Exp. Bot. 2009, 60, 2361-2377. [CrossRef] [PubMed]

23. Patrick, L.D.; Ogle, K.; Tissue, D.T. A hierarchical Bayesian approach for estimation of photosynthetic parameters of C3plants. Plant Cell Environ. 2009, 32, 1695-1709. [CrossRef] [PubMed]

24. Zhang, Y.; Guanter, L.; Berry, J.A.; Joiner, J.; van der Tol, C.; Huete, A.; Gitelson, A.; Voigt, M.; Köhler, P. Estimation of vegetation photosynthetic capacity from space-based measurements of chlorophyll fluorescence for terrestrial biosphere models. Glob. Chang. Biol. 2014, 20, 3727-3742. [CrossRef] [PubMed]

25. Schaefer, K.; Schwalm, C.; Williams, C.A.; Arain, M.A.; Barr, A.; Chen, J.M.; Davis, K.J.; Dimitrov, D.; Hilton, T.; Hollinger, D.Y.; et al. A model-data comparison of gross primary productivity: Results from the North American Carbon Program site synthesis. J. Geophys. Res. Space Phys. 2012, 117, 03010. [CrossRef]

26. Croft, H.; Chen, J.M.; Luo, X.; Bartlett, P.; Chen, B.; Staebler, R.M. Leaf chlorophyll content as a proxy for leaf photosynthetic capacity. Glob. Chang. Biol. 2017, 23, 3513-3524. [CrossRef]

27. Ju, W.; Wang, S.; Yu, G.; Zhou, Y.; Wang, H. Modeling the impact of drought on canopy carbon and water fluxes for a subtropical evergreen coniferous plantation in southern China through parameter optimization using an ensemble Kalman filter. Biogeosciences 2010, 7, 845-857. [CrossRef]

28. Vaz, M.; Pereira, J.; Gazarini, L.C.; David, T.; Rodrigues, A.; Marôco, J.; Chaves, M.M. Drought-induced photosynthetic inhibition and autumn recovery in two Mediterranean oak species (Quercus ilex and Quercus suber). Tree Physiol. 2010, 30, 946-956. [CrossRef]

29. Egea, G.; González-Real, M.M.; Baille, A.; Nortes, P.; Diaz-Espejo, A. Disentangling the contributions of ontogeny and water stress to photosynthetic limitations in almond trees. Plant Cell Environ. 2011, 34, 962-979. [CrossRef]

30. He, L.; Chen, J.M.; Liu, J.; Mo, G.; Bélair, S.; Zheng, T.; Wang, R.; Chen, B.; Croft, H.; Arain, M.; et al. Optimization of water uptake and photosynthetic parameters in an ecosystem model using tower flux data. Ecol. Model. 2014, 294, 94-104. [CrossRef]

31. Zhou, S.; Duursma, R.; Medlyn, B.; Kelly, J.W.; Prentice, I.C. How should we model plant responses to drought? An analysis of stomatal and non-stomatal responses to water stress. Agric. For. Meteorol. 2013, 182-183, 204-214. [CrossRef]

32. Zhao, S.; Wang, Q.; Yao, Y.; Du, S.; Zhang, C.; Li, J.; Zhao, J. Estimating and validating wheat leaf water content with three MODIS spectral indexes: A case study in Ningxia plain, China. J. Agric. Sci. Technol. 2016, 18, 387-398.

33. Zhu, X.; Wang, T.; Skidmore, A.; Darvishzadeh, R.; Niemann, K.; Liu, J. Canopy leaf water content estimated using terrestrial LiDAR. Agric. For. Meteorol. 2017, 232, 152-162. [CrossRef]

34. Junttila, S.; Sugano, J.; Vastaranta, M.; Linnakoski, R.; Kaartinen, H.; Kukko, A.; Holopainen, M.; Hyyppä, H.; Hyyppä, J. Can Leaf Water Content Be Estimated Using Multispectral Terrestrial Laser Scanning? A Case Study with Norway Spruce Seedlings. Front. Plant Sci. 2018, 9, 299. [CrossRef] [PubMed] 
35. El-Hendawy, S.E.; Al-Suhaibani, N.A.; Elsayed, S.; Hassan, W.M.; Dewir, Y.H.; Refay, Y.; Abdella, K.A. Potential of the existing and novel spectral reflectance indices for estimating the leaf water status and grain yield of spring wheat exposed to different irrigation rates. Agric. Water Manag. 2019, 217, 356-373. [CrossRef]

36. Zhang, S.Y.; Zhang, G.C.; Gu, S.Y.; Xia, J.B.; Zhao, J.K. Critical responses of photosynthetic efficiency of goldspur apple tree to soil water variation in semiarid loess hilly area. Photosynthetica 2010, 48, 589-595. [CrossRef]

37. Huang, Z.; Liu, Y.; Tian, F.-P.; Wu, G.-L. Soil water availability threshold indicator was determined by using plant physiological responses under drought conditions. Ecol. Indic. 2020, 118, 106740. [CrossRef]

38. Ullah, S.; Skidmore, A.K.; Naeem, M.; Schlerf, M. An accurate retrieval of leaf water content from mid to thermal infrared spectra using continuous wavelet analysis. Sci. Total Environ. 2012, 437, 145-152. [CrossRef]

39. Li, Y.; Song, H.; Zhou, L.; Xu, Z.; Zhou, G. Tracking chlorophyll fluorescence as an indicator of drought and rewatering across the entire leaf lifespan in a maize field. Agric. Water Manag. 2019, 211, 190-201. [CrossRef]

40. Song, X.; Zhou, G.; He, Q.; Zhou, H. Stomatal limitations to photosynthesis and their critical Water conditions in different growth stages of maize under water stress. Agric. Water Manag. 2020, 241, 106330. [CrossRef]

41. Farquhar, G.D.; Von Caemmerer, S.; Berry, J.A. A biochemical model of photosynthetic CO2 assimilation in leaves of C3 species. Planta 1980, 149, 78-90. [CrossRef] [PubMed]

42. Von Caemmerer, S. Biochemical Models of Leaf Photosynthesis; Csiro Publishing: Clayton, Australia, 2000.

43. Massad, R.-S.; Tuzet, A.; Bethenod, O. The effect of temperature on C4-type leaf photosynthesis parameters. Plant Cell Environ. 2007, 30, 1191-1204. [CrossRef] [PubMed]

44. Tuittila, E.-S.; Vasander, H.; Laine, J. Sensitivity of C Sequestration in Reintroduced Sphagnum to Water-Level Variation in a Cutaway Peatland. Restor. Ecol. 2004, 12, 483-493. [CrossRef]

45. Sun, Y.; Wang, H.; Sheng, H.; Liu, X.; Yao, Y.; Gong, C. Variations in internal water distribution and leaf anatomical structure in maize under persistently reduced soil water content and growth recovery after re-watering. Acta Physiol. Plant. 2015, 37, 1-10. [CrossRef]

46. Miyazawa, Y.; Tateishi, M.; Komatsu, H.; Iwanaga, F.; Mizoue, N.; Ma, V.; Sokh, H.; Kumagai, T. Implications of leaf-scale physiology for whole tree transpiration under seasonal flooding and drought in central Cambodia. Agric. For. Meteorol. 2014, 198-199, 221-231. [CrossRef]

47. Tobita, H.; Uemura, A.; Kitao, M.; Kitaoka, S.; Maruyama, Y.; Utsugi, H. Effects of elevated atmospheric carbon dioxide, soil nutrients and water conditions on photosynthetic and growth responses of Alnus hirsuta. Funct. Plant Biol. 2011, 38, 702-710. [CrossRef] [PubMed]

48. Varone, L.; Ribas-Carbo, M.; Cardona, C.; Gallé, A.; Medrano, H.; Gratani, L.; Flexas, J. Stomatal and non-stomatal limitations to photosynthesis in seedlings and saplings of Mediterranean species pre-conditioned and aged in nurseries: Different response to water stress. Environ. Exp. Bot. 2012, 75, 235-247. [CrossRef]

49. Wu, B.-J.; Chow, W.S.; Liu, Y.-J.; Shi, L.; Jiang, C.-D. Effects of stomatal development on stomatal conductance and on stomatal limitation of photosynthesis in Syringa oblata and Euonymus japonicus Thunb. Plant Sci. 2014, 229, 23-31. [CrossRef]

50. Ghannoum, O. C4 photosynthesis and water stress. Ann. Bot. 2008, 103, 635-644. [CrossRef]

51. Arry, M.A.J.P.; Andralojc, P.J.; Han, S.H.K.; Ea, P.E.J.L.; Eys, A.J.K. Rubisco Activity: Effects of Drought Stress. Ann. Bot. 2002, 89, 833-839. [CrossRef]

52. Galmés, J.; Ribas-Carbo, M.; Medrano, H.; Flexas, J. Rubisco activity in Mediterranean species is regulated by the chloroplastic CO2 concentration under water stress. J. Exp. Bot. 2010, 62, 653-665. [CrossRef] [PubMed]

53. Cai, Y.; Wang, J.; Li, S.; Zhang, L.; Peng, L.; Xie, W.; Liu, F. Photosynthetic Response of an Alpine Plant, Rhododendron delavayi Franch, to Water Stress and Recovery: The Role of Mesophyll Conductance. Front. Plant Sci. 2015, 6, 1089. [CrossRef]

54. Lin, X.; Xu, Z.; Wang, Y.; Zhou, G. Modeling the responses of leaf photosynthetic parameters of Leymus chinensis to drought and rewatering. Acta Ecol. Sin. 2008, 28, 4718-4724. [CrossRef]

55. Cai, F.; Zhang, Y.; Mi, N.; Ming, H.; Zhang, S.; Zhang, H.; Zhao, X. Maize (Zea mays L.) physiological responses to drought and rewatering, and the associations with water stress degree. Agric. Water Manag. 2020, 241, 106379. [CrossRef]

56. Hgaza, V.K.; Diby, L.N.; Aké, S.; Frossard, E. Leaf growth and photosynthetic capacity as affected by leaf position, plant nutritional status and growth stage in Dioscorea alata L. J. Anim. Plant Sci. 2009, 5, 483-493.

57. Yan, W.; Zhong, Y.; Shangguan, Z. Responses of different physiological parameter thresholds to soil water availability in four plant species during prolonged drought. Agric. For. Meteorol. 2017, 247, 311-319. [CrossRef]

58. Wang, J.; Zhao, C.; Huang, W.; Guo, X.; Li, H. Effect of soil water content on the wheat leaf water content and the physiological function. J. Triticeae Crop. 2001, 21, 42-47.

59. Soltani, A.; Khooie, F.; Ghassemi-Golezani, K.; Moghaddam, M. Thresholds for chickpea leaf expansion and transpiration response to soil water deficit. Field Crop. Res. 2000, 68, 205-210. [CrossRef]

60. Xia, J.; Zhang, S.; Guo, J.; Rong, Q.; Zhang, G. Critical effects of gas exchange parameters in Tamarix chinensis Lour on soil water and its relevant environmental factors on a shell ridge island in China's Yellow River Delta. Ecol. Eng. 2015, 76, 36-46. [CrossRef] 